\title{
Research infrastructure, networks of science and re- gional development - the case of Oskarshamn
}

\author{
Folke Valfrid Snickars ${ }^{1}$, Ulf Karlsson ${ }^{2}$ \\ ${ }^{1} \mathrm{KTH}$, Stockholm, Sweden \\ ${ }^{2}$ Linköping University, Linköping, Sweden
}

Received: 15 July 2016/Accepted: 13 September 2017

\begin{abstract}
Final disposal of nuclear waste is a global engineering challenge. The Swedish nuclear industry has consequently spent more than thirty years investigating the best sites and technologies for the final storage of nuclear waste. Universities have been involved as experts in this large-scale R\&D activity. This has resulted in a well-documented body of knowledge for supporting relevant decision-making. Simultaneously, as a result, global research infrastructure networks have been developed and consequently more than 140 $\mathrm{PhD}$ theses have been produced. Eleven of these PhD holders are now full professors.

Based on earlier work on research infrastructures from Lund, Hamburg, and Kiruna, see for instance Snickars, Falck (2015), we have addressed the question of the role of a technical research infrastructure in the development of the fields of engineering and natural science while simultaneously generating regional development. It has provided an opportunity to empirically study the use of research infrastructure in a specialized technology field. At the same time, this study investigates one municipality's efforts to specialize in research without a university in the vicinity.

Do networks of cooperation differ between research groups and research infrastructures? How can a region build its smart specialization on research infrastructure? How can research equipment once belonging to a company be transformed to a public research infrastructure asset?

Our results indicate that research infrastructures such as the ones in Oskarshamn are powerful creators of international research networks. It is possible, although somewhat difficult in view of scattered systems for data provision, to assess their academic and societal impacts. Engineering research has its own networks of university-industry and industry-university interaction where project-based value is cogenerated dynamically. In this study, we have come some way towards empirically analyzing the networks of research cooperation between industry and university using methods of infrastructure and social network analysis.
\end{abstract}

\section{Introduction}

Final disposal of nuclear waste is a global engineering challenge with solutions varying by country since the trading of waste is not generally a politically viable solution as it is in other waste management areas. Research infrastructure networks can potentially be used as a basis for the transformation of test sites to complementary uses. Dynamic micro analysis can be performed since there is an ample supply of data, albeit less than 


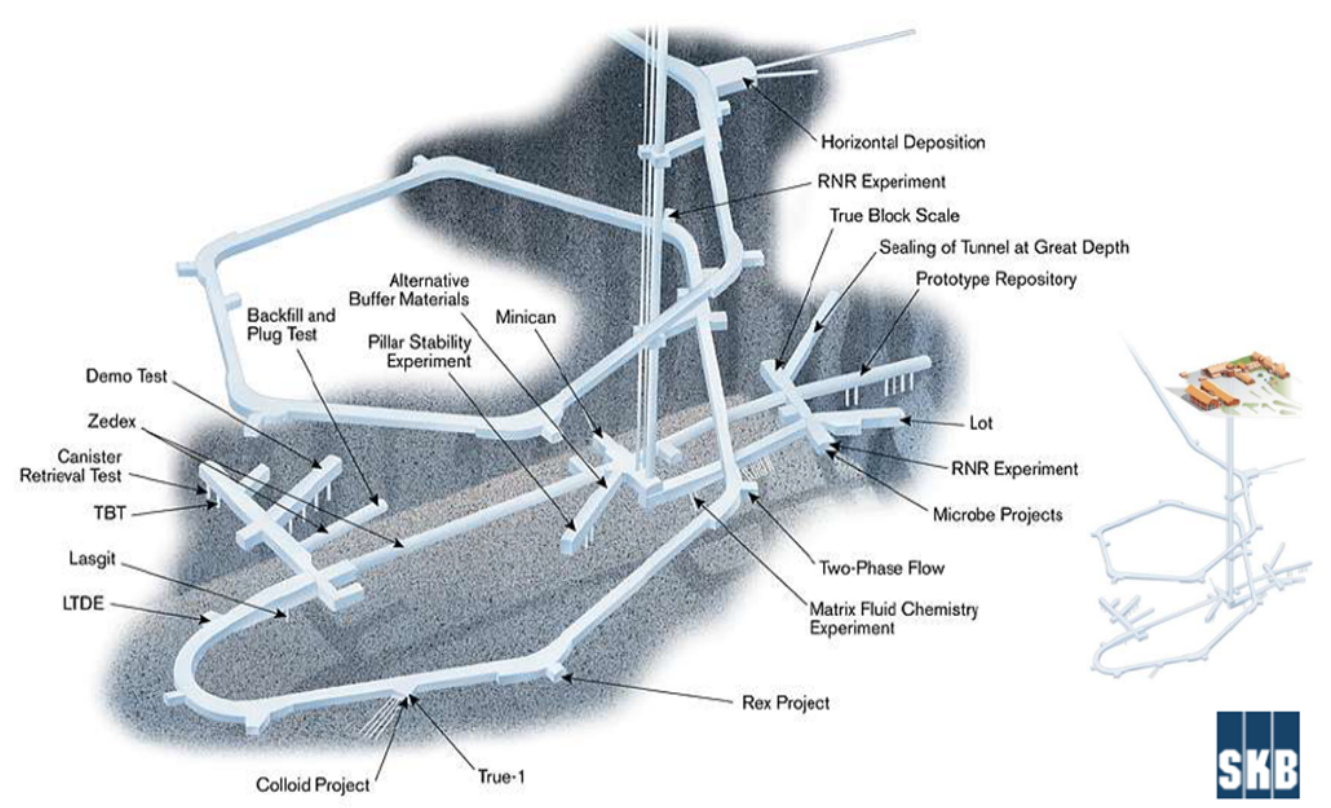

Figure 1: The underground test installations in the Äspö Hard Rock laboratory including names of major experiments

organized. The mutual trading of knowledge between industry and universities involving effective policy schemes can be an interesting spillover mechanism.

Using the Äspö Hard Rock laboratory as a case study, research questions to be addressed in the current paper are as following:

- What quality of science can be generated in an industrial development project?

- How can an experimental research facility belonging to a company be transformed into a public research infrastructure?

- How can a region foster smart specialization through a research infrastructure?

Oskarshamn in southeastern Sweden is the location of one of three nuclear power stations, the primary site for intermediate storage of nuclear waste and the main experimental site for testing technologies for final storage. A decision has been made to store waste in Forsmark northeast of Stockholm for the long-term. National resources are available to assist Oskarshamn in a smooth transformation to another, smarter industrial specialization. The question is, can resources be transformed into new uses in an experimental mine, building on local competence, environmental resources, and international investments in research cooperation?

The core innovation idea is to transform the environment, which is illustrated in Figure 1, to a geosphere laboratory and develop this in the long term as an international research infrastructure in engineering science.

The Äspö laboratory has a depth of some 500 metres and is located on an island within the security zone of the nuclear power plants outside Oskarshamn in a nearby archipelago. Its main mission has been to test the viability and security aspects of storage of nuclear waste. The prototype repository experiment is located in one part of the underground facilities. Other parts are used for the testing of bedrock, and rock drilling properties as well as various environmental experiments to further the understanding of how radioactivity spreads in an underground bedrock environment. 


\section{The Äspö Hard Rock laboratory in SKB activities}

Surveying work began at Äspö in 1986, as the Swedish Nuclear Fuel and Waste Management Company (SKB) wanted to explore the possibility of building an underground laboratory there. This was the beginning of the research and technological development

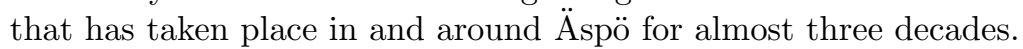

It was in its 1986 research, development and demonstration programme that SKB presented the first plans to construct its own underground laboratory. These plans extended from 1987 until 2010 and included for instance detailed studies of natural barriers and their function in a final repository, developing methods and technologies for final disposal as well as demonstrating what its different sections would look like.

The first development measures were already under way before construction of the laboratory had begun. In preparation for, and during construction work, different methods of studying bedrock from the surface were tested. Later the rock was studied in detail in tunnels and shafts. These methods were then used for the comparative site investigations at Forsmark and Oskarshamn before the final choice of Forsmark as the site of the spent fuel repository was made.

The experiments performed at Äspö were collected into a comprehensive database, called Sicada, which now holds the preconditions and results of a 30-year period of experiments, and environmental measurements. The database also comprises information about environmental conditions in the area around the mine itself. It is one of the largest such databases in the world. SKB has also kept track of its research projects which have been organized in a series of three year research and development programmes. There are now around ten programmes in total and documentation on the main results of each programme is currently available.

The activities of SKB can be seen as a large industrial development project. The ultimate goal is to propose a viable and secure technical system to store the nuclear waste in the bedrock forever. A proposal from SKB for this technology is currently being assessed in the Swedish legal system. The assessment will take several years and might lead to a further need for investigations by the Äspö laboratory. The actual depositing of waste is not foreseen to take place before the middle of the 2020s.

The goal of the current paper is to use the publication databases of SKB to estimate some of the scientific and industrial impacts of the research activities at Äspö. The focus will be on publications in a broad sense as they exist in the public databases of SKB. We will characterize the publication patterns reported by SKB in terms of volumes, types of publication, main researchers, and industrial collaboration. In this regard, we will attempt to assess the scientific impact of the work at Äspö for the researchers, and disciplines involved.

We will provide some basic information about SKB as a starting point for the analysis of publication networks. The presentation will concern SKB as a whole, since it is not possible to separate activities at $\ddot{A}$ spö from other research activities in the company records. Figure 2 illustrates the total production value of SKB across time.

The total production level was about 1.73 billion SEK in the maximum year 2012 . The sharp rise in the production level after 2010 has to do with changes in the company accounting. Even if this is the case the yearly resource use is substantial, for instance, in comparison to the volume of resources used for research in a medium-sized technical university.

Figure 3 illustrates the role of research costs in the company across time. We see a steady decline in the yearly allocations to research both in terms of costs and personnel. The share of research personnel was 40 percent in 2000 and had fallen to 22 percent in 2013. The decline in cost terms is even sharper, reflecting the simple fact that SKB has been approaching the end of its research and development programme.

\section{Literature review}

The analysis is based on earlier work on research infrastructures in Lund, Hamburg, and Kiruna where the emphasis has been on already well-established research infrastructures, 


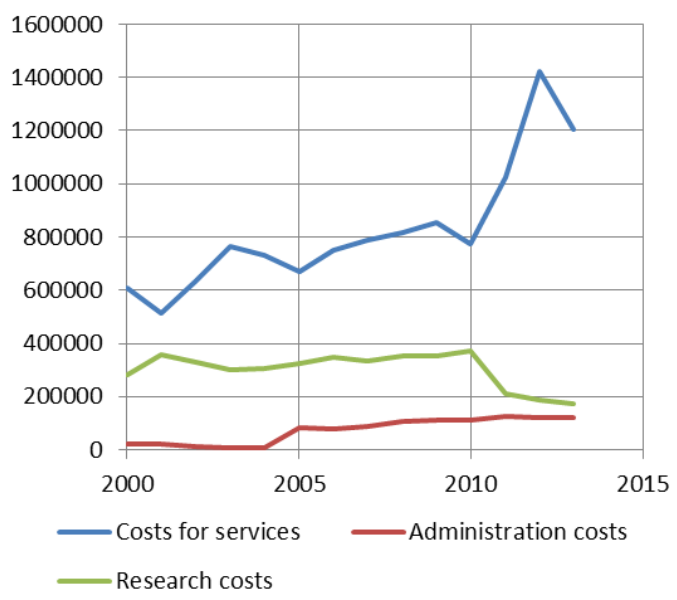

Notes: kSEK current prices

Figure 2: Composition of SKB production system 2000-2013

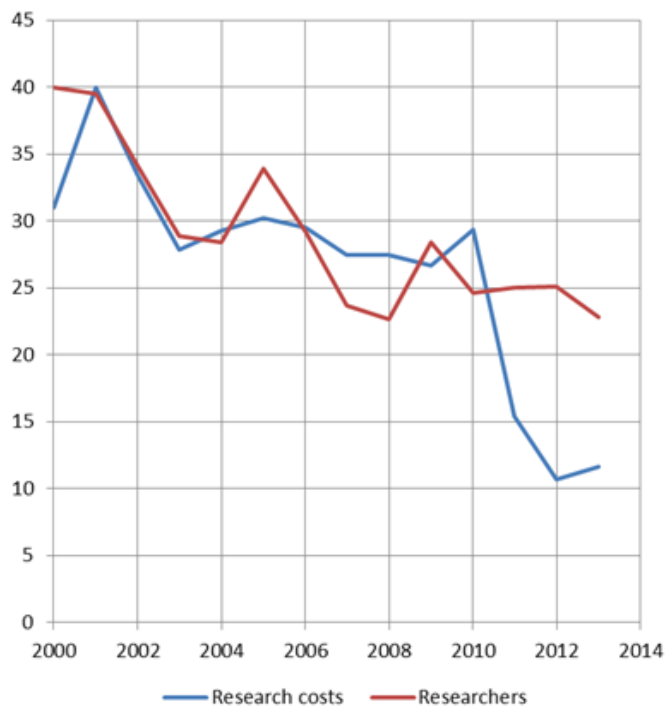

Notes: in percent

Figure 3: Share of resources allocated to research within SKB 2000-2013)

see Falck et al. (2011) and Snickars, Falck (2015). Those studies have formed part of the input to proposals for new Swedish and EU road maps for research infrastructure raising the question of the importance of those infrastructures for regional development. If such effects can be shown this will add both to the scientific value of investments, as well as the use of EU structural funds and related investment programmes to generate even broader societal impacts.

The Oskarshamn case provides an opportunity to empirically study the use of research infrastructure in a highly specialized technology field where activities are performed in a parallel fashion by university researchers, and development-oriented firms and consultants. In our earlier studies, the starting point has been basic research in physics and the question has been whether this research can be proved to have industrial and societal impacts. In the current study, the starting point is an advanced technological development project in the nuclear field and a central question has been whether this development project has had measurable scientific impacts. A further question is how important and lasting the collaboration has been for the firms, and thus for the impacts on regional development and growth. 
The current case study also provides an opportunity to test contemporary theories on the knowledge industry and its mechanisms for the generation and diffusion of knowledge spillovers and innovations. The work is based on thought models in Mellander, Florida (2007), Andersson, Beckmann (2009), Helmers, Overman (2013) and Batabyal, Nijkamp (2015). The case also provides a challenge to study a municipality's efforts to specialize in research and development without a university in the region or even in the vicinity of the region, see also OECD (2012).

Prior work has largely been focused on externalities between firms, or alternatively university-industry linkages, emphasizing localized knowledge spillover effects and functional regions as arenas for knowledge flows, see also Snickars, Falck (2015). Horlings et al. (2012) argue that the existing literature provides no direct empirical evidence demonstrating that impacts actually occur around scientific research facilities and that there is insufficient evidence to support the claim that such investments will, for instance, attract and retain talent and promote innovation.

Helmers, Overman (2013) is one of the first studies to provide empirical evidence on the relationship between agglomeration and a large-scale scientific research infrastructure. Their study considers agglomerative effects of investments in a so-called synchrotron light source in the United Kingdom, and found that the establishment of the Diamond Light Source in Didcot induced clustering of related research activities and increased the research output of nearby organizations, as well as of organizations that did not utilize the facility.

Rekers (2013) has theoretically portrayed the European Spallation Source (ESS) as an enormous addition to the innovation-based economy of the Öresund region. She argues that the anticipated local benefits associated with ESS are tied to the degree of embeddedness of the facility in regional knowledge networks that facilitate localized learning. However, it is also emphasised that innovative work is inherently uncertain, unanticipated and non-linear, where investments do not directly and predictably lead to successful outputs. The counter-argument is rather that impacts can be proactively created.

Johansson, Quigley (2004) argue that networks may provide some or all of the external utility gains derived from agglomeration since knowledge networks that comprise linkages into the global scientific community enlarge the pool of specialized workers that can be considered as interregional sources of new and diverse knowledge.

The research on the impact and utilization of non-large-scale research facilities appears very limited. Falck et al. (2011) have attempted to explicitly demonstrate how the MAX synchrotron facility in Lund is utilized by researchers across the world and whether there is scope to consider MAXlab as a research infrastructure with regional implications. The main result from this study is that it is not possible to consider MAXlab as a regional research facility without considering the importance of its Nordic, European, and global linkages

The current study can also be conceived through the framework of recent attempts to provide a comprehensive map of the pathways to impact of scientific research, see for instance Snickars et al. (2013). Academic impacts have several interconnecting dimensions. A research project, research program, or research infrastructure, can also generate a wide variety of social and economic impacts. These impacts occur in different time scales but also on different spatial scales. Since research is an activity performed in an open global environment, economic and social impacts may also occur regionally, nationally, and internationally. Snickars, Falck (2015) argue that since the Kiruna-based radar station EISCAT has been for a long time identified as a research infrastructure of international importance, its impacts have surely occurred in the global environment. EISCAT has been selected as a top-priority EU research infrastructure.

\section{Research and development outputs}

SKB details its plans for continued research and technological developments every third year in a special R\&D programme which commenced in the 1980's. The most recent one was released in 2013. In this context, however, we will not deal with the scientific substance 
Table 1: Äspö publication pattern by type 1993-2013

\begin{tabular}{lrrrrrr}
\hline From & 1999 & 2002 & 2005 & 2008 & 2011 & 1999 \\
To & 2001 & 2004 & 2007 & 2010 & 2013 & 2013 \\
\hline Article & 13 & 8 & 26 & 4 & 32 & 83 \\
Proceedings & 22 & 13 & 22 & 1 & 5 & 63 \\
Report & 113 & 176 & 67 & 52 & 28 & 436 \\
Thesis & 25 & 20 & 23 & 22 & 12 & 102 \\
Total & 173 & 217 & 138 & 79 & 77 & 684 \\
\hline
\end{tabular}

of this comprehensive research portfolio, but instead concentrate on the networks within science generated by the research, and on the linkages to industrial development activity.

An international review of SKB's research and development efforts was made in 2012, see Nuclear Energy Agency (2012). This review emphasized the importance for SKB to clearly show the chain of events whereby theory is transformed into practice, including how to translate safety analyses into industrial production and application. This work will become increasingly important closer to the start of construction and operation of the final storage facility in Forsmark. The results of this work are currently reviewed and evaluated by the Swedish Radiation Safety Authority (SSM), in a comprehensive licensing process. The NEA review report praises SKB's approach to public outreach work that is described as at the forefront of international practice.

A major part of the research reported in the current paper has been generated by merging publication data from different sources within SKB. The central source of data has been the yearly reports on the publication output from researchers involved in the SKB research programme. These publications consist of both technical reports, proceedings from workshops and conferences, and academic papers published in peer-reviewed journals, see SKB (1994 2014) and SKB (2013).

The composition of these outputs of the research and development projects is summarized in Table 1 which is constructed from yearly reports for the period 1998-2013 and contains some 700 publications. We note that four out of seven of the recorded publications are technical reports and that a rather small number of publications are recorded as articles.

The funding profile of the research done at the Äspö laboratory is shown to decline across time (Figure 2 and 3 ). This does not necessarily mean that the publication output follows the same pattern. Figure 4 illustrates that the publication level was highest in the period between the end of the 1990s and the middle of the first decade of the 2000s. About 120 publications per year were then produced. The latest ten-year period has exhibited a steady fall in the number of publications as indicated by the relevant yearly reports.

Since research on final disposal is a complex engineering challenge it might be expected that joint publication would be relatively common. Figure 5 illustrates this pattern for the period 1998-2011. We observe that about half of the publications are single-authored with a tendency of this ratio to increase across time. Around one third of the publications have two authors while the share of publications involving three or more authors is one out of five.

We also observe that the share of publications with two authors has remained stable over time. Instead bigger networks of cooperation have been split and more publications have been single-authored. This would seem to indicate that the share of technical reports has also decreased over time as the need for large-scale experimental setups has been reduced.

The total output of $\mathrm{PhD}$ degrees has been in the order of seven per year producing a total of 143 dissertations. The $\mathrm{PhD}$ degrees have been awarded from a wide set of Swedish and international universities with a focus on the major technical universities in Sweden, especially the Royal Institute of Technology. Four of the dissertations have been produced at non-Swedish universities, see Figure 6.

The dissertations have been an initial part of the career of the persons involved. We 


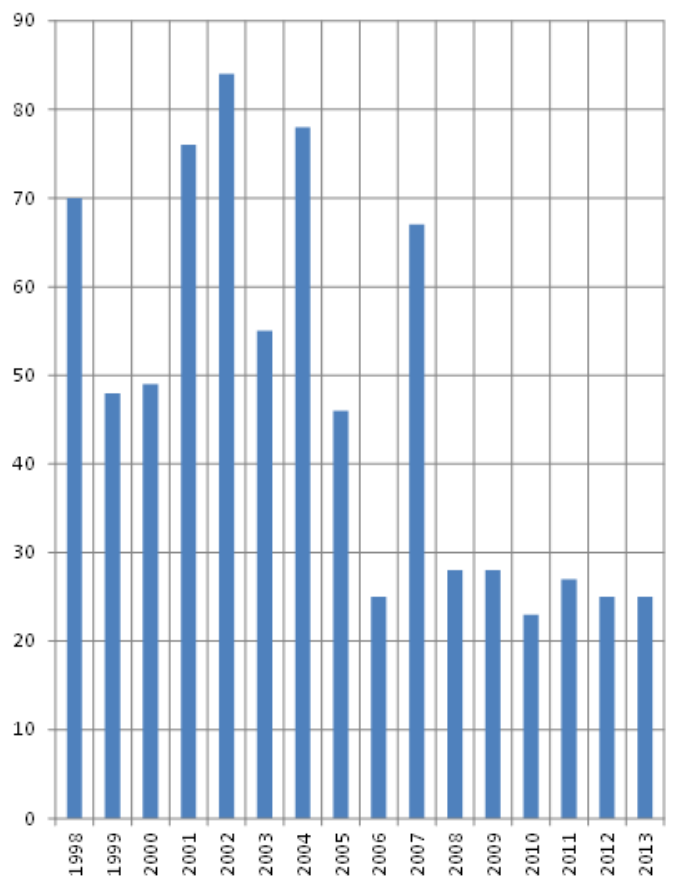

Figure 4: Publications based on experiments at Äspö hard rock laboratory 1998-2013

have followed these careers by tracking down the current affiliation and work title of each of the doctoral students using $\ddot{A}$ spö as their experimental area, see Figure 7 for an illustration.

In this way, it is possible to characterize an important part of both the academic and the industrial footprint that the Äspö test site has implicitly generated. We will outline the development for dissertations finished during each of the three-year SKB research plans.

We note that eleven of the 143 persons having written their dissertations on results from experimental work performed at the Äspö hard rock laboratory are full professors in 2016. This is somewhat less than one out of ten. Somewhat more than one out of ten has reached director positions in the private or government sector. The bulk of the degree holders have research or management positions. The share of degree holders who are found outside academia increases substantially over time.

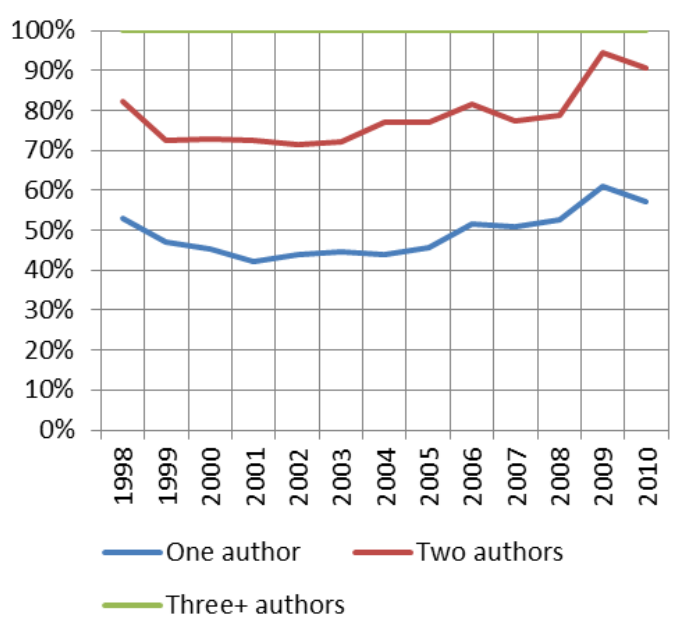

Figure 5: SKB articles according to number of authors across time 1997-2011 


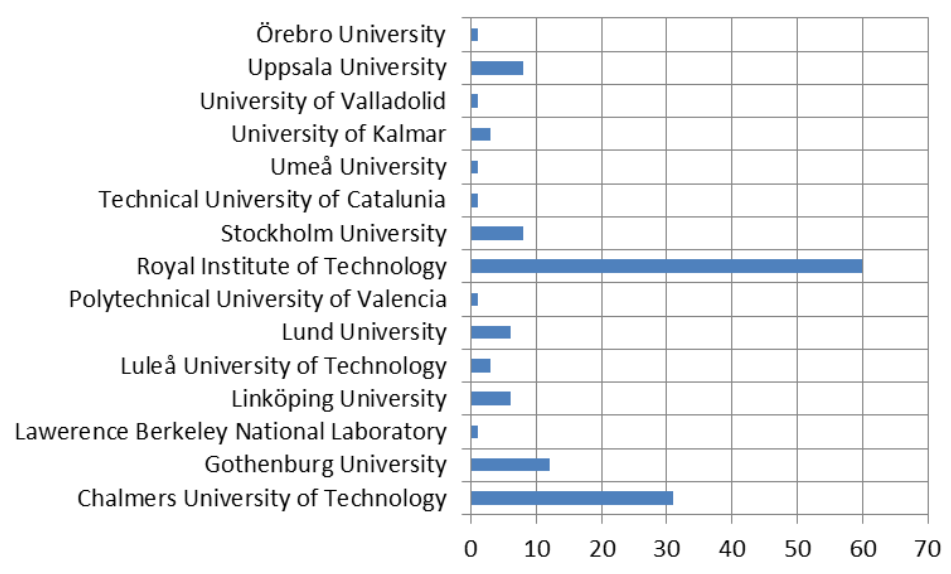

Figure 6: University affiliations of PhDs using Äspö Hard Rock laboratory 1992-2013

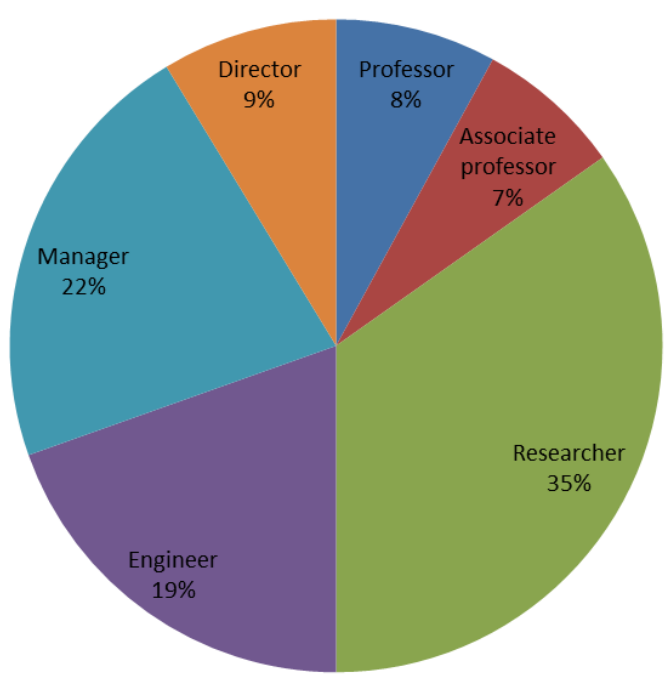

Figure 7: Current work positions for doctoral students using the Äspö hard rock laboratory 1992-2013

One can conclude that an important output of the activities at Äspö has been the production of academic, industrial and management competence for the technology area.

\section{Research cooperation and publications}

The research and development work at Äspö has been mostly concentrated on testing alternative technologies for the transport, deployment, and storage of nuclear waste. Another focal area has been performing scientific modelling and testing properties of the bedrock in which storage facilities are to be prepared and the waste stored safely for a very long time. For these reasons, documentation of the work has had to be done very carefully so that one can verify results achieved at later points in time.

A comprehensive database, called Sicada, has been set up which also contains systematic measurements of external environmental conditions in the biosphere around Äspö. These arguments indicate that the research and development work has involved a large amount of teamwork, and a large amount of jointly produced publications. However, we have not set up a database for each research project but rather focused on the publications emerging from these projects as they are presented in the yearly reports from SKB.

Figure 8 provides an illustration of patterns of collaboration with non-university organizations as reflected in the publication records from the Äspö hard rock laboratory. 


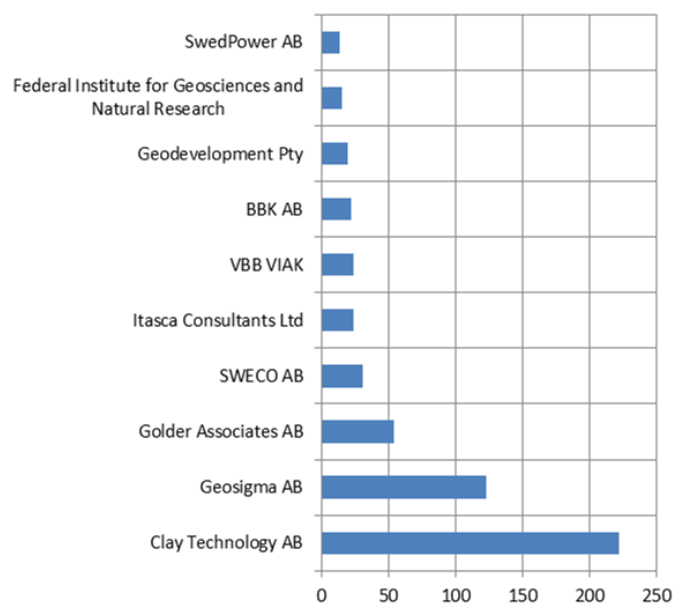

Figure 8: Number of co-authorships involving non-university organizations in publications from Äspö hard rock laboratory 1998-2013

The figure reveals that the most frequently occurring company name is Clay Technologies. It comes as no surprise that this is the company at which two of the leading scientists have been working. The author with the largest number of mentions in the database seems to be working both from his base at Gothenburg University and from his geoengineering consulting company. This observation also holds in a more general sense. It seems that a number of scientists have acted from both university departments and private enterprise platforms in their work at the laboratory.

We can note from the company names shown in Figure 8 that industrial cooperation extends to both Swedish and international companies. Some companies seem to be rather small and very specialized towards the Äspö context. Other networks seem to involve some major Swedish civil engineering consultants who have a specialization in rock mechanics and tunneling.

The pattern observed here is quite different from what may be observed in relation to other research infrastructures. The Äspö case shows that a major technological problemsolving effort can give rise to scientific development, create new academic subjects and provide challenges to existing engineering science.

\section{Network analysis of research cooperation}

Scientific work depends on the free access to earlier research results. Some publications will be disseminated widely and then effectively function as capital inputs to the ongoing research. The notion of academic impact factors stems from this observation. Highly cited scientists then effectively work as research leaders even if there is no formal connection between the leaders and the followers. In the context of the current case of the Äspö hard rock laboratory we might ask which researchers are the research leaders by analyzing the publication database in terms of patterns of joint authorships. Is it possible to identify subgroups of researchers through the publication analysis?

From the perspective of network theory (Johansson, Quigley 2004), researchers' affiliations are network nodes and co-authorships establishes edges between the nodes. As a result, nodes and edges form pairwise linkages including link-weights for each publication, where linkages indicate joint-publications and link-weights indicates the number of joint-publications between a specific pair. Double back relationships between nodes are controlled for so that each pairwise linkage is unique. The visual exploration of the networks is made using the Gephi software package, see for instance Bastian et al. (2009). The analysis will again be based on publication patterns found in the yearly reports from SKB.

Figure 9 gives an overview of the results. It is obvious that there are groupings of researchers who collaborate with other persons in their fields of science. Some of these 


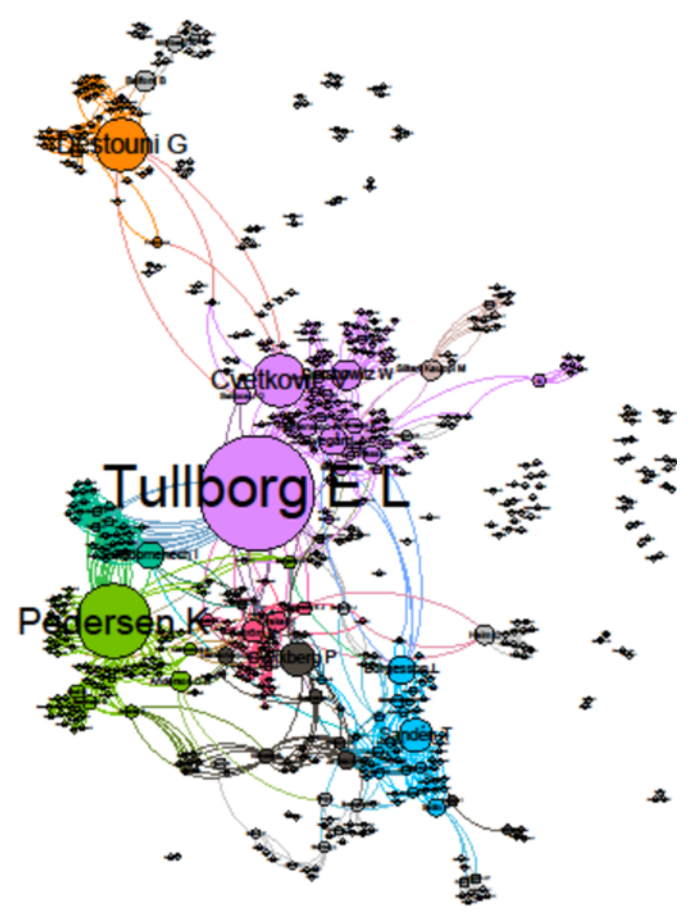

Figure 9: The research network of Äspö-based activities according to SKB yearly reports 1998-2013

groups are independent of the core group, while others are peripheral without belonging to a certain group. In the current case, these are persons who have contributed to the test programmes without having scientific ambitions of their own.

The size and positioning of the persons in the network is determined by the so-called betweenness centrality measure, see Freeman (1977). The indicator measures all the shortest paths between every pair of nodes of the network and then counts how many times a node is on a shortest path between two others. It is a very revealing measure in the case of a network of scientists as it allows us to detect people that occupy an intermediate transfer position between other people or groups.

We note from the figure that some of the researchers who have published the most are not central to the network. Conversely, others stand out as hubs around whom most of the research and development work has emerged during the fifteen-year period investigated. We have partitioned the graph so that those researchers who have the closest affinity in terms of joint publications share the same colour. Seven major groupings have been identified.

Figure 10 shows research networks resulting in academically published articles linked to the Äspö Hard Rock laboratory according to organizational home 1998-2014, see also Falck, Snickars (2017).

As we can see the research activity is characterized by cooperation between researchers from Sweden and other countries. More specifically, among the 90 articles shown in Figure 9 which have been authored by more than 200 persons in more than 70 different research institutions in 18 countries, a small minority do not build on inter-organizational cooperation.

We can conclude that the strategic importance of the Äspö Hard Rock laboratory is not only connected to the task of developing technology for the final disposal of nuclear waste but has also implied strategic research cooperation between researchers in university and industry. This strengthens the position of Sweden as a research nation. The presence of such cooperation accounts for spillover effects in the whole knowledge production system through informal social networks. These effects are not confined to the nuclear industrial networks 


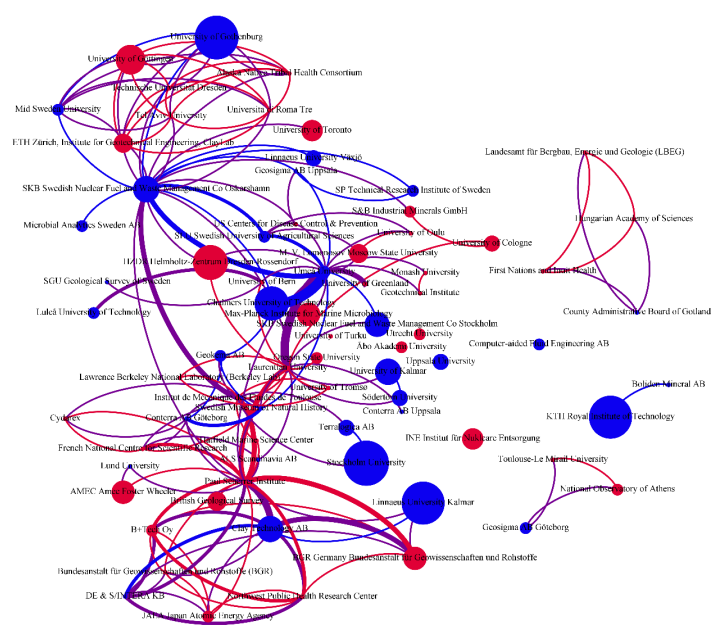

Notes: Blue=Swedish organization, Red=International organization. Node size representsnumber of published articlesto which organiations mentioned have contributed. Link thickness indicates number of coauthored and colour (red/blue/purple) 1998-2014

Figure 10: Research networks resulting in academically published articles linked to the Äspö Hard Rock Laboratory according to organization 1998-2014

From a strategic perspective it is not only the presence and volume of research activities which is important but also how the projects have been organized. Projects involving actors from different organizations provide non-monetary benefits which spill-over within the network. The Äspö Hard Rock laboratory has therefore acted as a catalyst for new engineering science and new engineering practices.

\section{Conclusions}

This study examines the economic and societal importance of the Äspö hard rock laboratory, including the nature, scale, and spatial configuration of related scientific work and other activities. It demonstrates that the nuclear installations in Oskarshamn may give rise to specialized local labour markets, increased human capital levels, consumption of local goods and facilities, and perhaps also functions as a magnet for highly-skilled professionals. It appears, however, that the Äspö laboratory neither resulted in any substantial clustering of related activities nor has it generated any significant economic effects in the short and medium term. Instead, it contributes to strengthen regional competitiveness and attractiveness in a more general sense, suggesting the economic and societal importance of the Äspö laboratory as a knowledge infrastructure is long term and should be interpreted in a strategic context.

There are additional aspects of Oskarshamn as an important node in the nuclear cluster in southeastern Sweden, which includes several complementary organizations such as the encapsulation plant, the central interim storage facility for spent nuclear fuel, the canister laboratory and the bentonite laboratory. The long-term work of SKB in general and the Äspö laboratory in particular has thus implied a large injection of research funding across time in the region.

Another important aspect of the Äspö laboratory is as an interconnecting infrastructure and organization in value creating knowledge networks with global reach. The gains from these network linkages or global knowledge pipelines relate to transactions of formal and informal knowledge and other advantages including memberships in scientific communities that contribute to renewal and dynamism of local knowledge. These network linkages may imply the same type of external utility gains derived from any agglomeration of similar or dissimilar activities, and can be expected to arise from extra-regional sources of new and diverse knowledge. 
However, the related development work needs to carefully consider how to promote a high level of absorptive capacity among organizations with related activities. This is in order to maximize the potential benefits of hosting an advanced scientific research infrastructure and to facilitate localized learning and thus contributing to strengthen the nation and region as well as the city of Oskarshamn in a sustainable way.

In terms of the classification of impacts presented in Snickars et al. (2013) a number of observations can be made. First, the main impacts of the Äspö laboratory stay within the technological system related to nuclear technology. It simultaneously creates worldwide academic advancement through the use of innovative equipment, techniques and technologies in a cross-disciplinary setting. The existence of the infrastructure in southeast Sweden has a positive side-effect for the training and teaching of students at academic levels in several Swedish universities engaged in nuclear-related research and education.

The Äspö laboratory as a part of the SKB system has played a role in creating social and economic impacts but there is no distinct profile outside the energy sector. It is clear that SKB's activities increase public engagement and interest in research related to energy in general and nuclear energy in particular.

The fact that this research has been effectively performed in Oskarshamn clearly adds to the role of southeast Sweden as an energy cluster. This aspect of Äspö could be further promoted through deepened studies of the current type for other infrastructures. The geosphere-related development at Äspö may enhance quality of life in view of its attractiveness for cultural tourism.

In summary, it might be said that there is a clear potential to promote social and economic impacts of the energy sector in Oskarshamn especially if one considers the sector as a whole. In this context, it is interesting to observe that the Äspö laboratory can have a very strong role in the national research infrastructure system in Sweden, and at the European level. It can be related to other research infrastructures at the European level for which Sweden has been selected as the host. This international visibility does not seem to fully penetrate to the level of regional and local decision making. There is room for action for instance in relation to the new policy round within the structural funds.

We conclude by providing answers to the research questions posed in the introduction:

- Research infrastructures as the Äspö Hard Rock laboratory are powerful and productive creators of international research and research networks;

- It is possible although technically somewhat difficult to reveal the academic and societal impacts of Äspö-related research and development which become visible if the perspective in broad enough;

- Engineering research has its own peculiar networks of university-industry interaction where value is cogenerated dynamically which makes it a challenge to specialize in it for a peripheral region.

We have come some way in analyzing the productivity of research cooperation using the case of Äspö as a test area but considerably more work needs to be done both to enhance the quality of the background data and to demonstrate the knowledge valorization chains.

\section{Acknowledgement}

We acknowledge economic support from the municipality of Oskarshamn in performing the research reported in the current paper. We also thank SKB library staff for allowing access to project and publication data.

\section{References}

Andersson ÅE, Beckmann M (2009) Economics of knowledge: Theory, models and measurements. Edward Elgar, Cheltenham 
Bastian M, Heymann S, Jacomy M (2009) Gephi: An open source software for exploring and manipulating networks. International AAAI Conference on Weblogs and Social Media

Batabyal A, Nijkamp P (2015) Creative capital in production, inefficiency, and inequality - a theoretical analysis. Paper presented at an international workshop, Tinbergen Institute, Amsterdam

Falck S, Snickars F (2017) Societal benefits of the Äspö hard rock laboratory. Research report, Department of Urban Planning and Environment, KTH

Falck S, Snickars F, Westlund H (2011) Research hubs in the Baltic sea region: An explorative study about research cooperation and the usage of research facilities in physics and life sciences. Research paper, Royal Institute of Technology (KTH) and the Swedish Research Council (VR)

Freeman L (1977) A set of measures of centrality based on betweenness. Sociometry 40: 35-41. CrossRef.

Helmers C, Overman HG (2013) My precious! The location and diffusion of scientific research: Evidence from the synchrotron diamond light source. SERC Discussion Papers, SERCDP0131. Spatial Economics Research Centre (SERC), London School of Economics and Political Science, London

Horlings E, Gurney T, Somers A, van den Besselaar P (2012) The societal footprint of big science - A literature review in support of evidence-based decision making. Working paper 1206, Rathenau Instituut, Den Haag

Johansson B, Quigley JM (2004) Agglomeration and networks in spatial economies. Papers in Regional Science 83: 1-13. CrossRef.

Mellander C, Florida R (2007) The creative class or human capital? - Explaining regional development in Sweden. Working paper series in economics and institutions of innovation 79, Centre of Excellence for Science and Innovation Studies, KTH. CrossRef.

Nuclear Energy Agency (2012) The post-closure radiological safety case for a spent-fuel repository in Sweden. An international peer review of the SKB license-application study of March 2011. NEA/RWM/PEER(2012)2, OECD, Paris

OECD (2012) Oecd territorial reviews, småland - blekinge. Research report, OECD, Paris

Rekers JV (2013) The european spallation source (ESS) and the geography of innovation. In: Kaiserfeld T, O'Dell T (eds), Legitimizing ESS: Big Science as a Collaboration Across Boundaries. Nordic Academic Press, Lund

SKB (1994-2014) Äspö hard rock laboratory annual report 1993-2014. Technical reports

SKB (2013) RD\&D programme 2013. Technical report, TR-13-18

Snickars F, Blaus J, Eriksson T, Reitberger G (2013) Economic and social impacts of kth research: A follow-up study of the research assessment exercise 2012. Research report, VINNOVA and KTH

Snickars F, Falck S (2015) Inter-regional trade in research-based knowledge: The case of the EISCAT radar system. In: Batabyal A, Nijkamp P (eds), The region and trade: New analytical directions. World Scientific, London, 227-264. CrossRef. 